\title{
Racial Appearance And Income In Contemporary Mexico
}

Rutilio Martinez, University of Northern Colorado, USA

Cris de la Torre, University of Northern Colorado, USA

\begin{abstract}
In Mexico, income and European appearance are strongly positively correlated. Racist attitudes, overt preference for the European appearance and high unemployment combine to maintain this racial economic hierarchy. Free market policies could help to reduce the racial economic inequality. These policies, however, go against the economic interests of the wealthy white oligarchy and against the prevailing political ideology of the dark skinned lower classes. Thus, the current racial economic inequality, with its negative economic consequences, is likely to continue.
\end{abstract}

Keywords: European appearance, Mestizo, Indian, dark-skinned, unemployment, overt preference.

\section{INTRODUCTION}

ndividuals of mixed European and Indian background, the Mestizos, represent $60 \%$ of the population.
The rest of the population is 30\% Indian, 9\% white and $1 \%$ other (Central Intelligence Agency, 2006) ${ }^{1}$.
Income and wealth are distributed very unequally among these racial groups. The oligarchy is exclusively white, and whites are the vast majority in the wealthy social class immediately below it. Next in the economic hierarchy are the Mestizos. Within the Mestizos, however, there is a discernable economic pecking order, with those of predominantly European features, especially light skin, the white/Mestizos, ahead of those with predominantly Indian traces, like dark skin. At the bottom are the Indians, who are the majority in the two poorest deciles (Wagley, 1994, pp. 1-7; Hall \& Patrinos, 2004, pp.4-7; Stavenhagem, 1994, p.331; Nevaer, 1995, p.102 ). That is, there is a strong positive correlation between European appearance and income in Mexican society.

The attitudes of Mexicans towards this racial economic hierarchy are varied. Some are oblivious to it, some deny its existence, some see it as a result of rigid social classes, and some consider it a remnant of the social and economic structures of pre-revolutionary Mexico. Most Mexicans, however, are firmly convinced that racism or any sort of racial preferences are not the cause of this racial economic hierarchy. This conviction would be easy to accept if it were not for one noticeable social fact, namely: the overt preference for the European appearance across society. In this paper it is argued that this preference, when combined with high unemployment, affects the distribution of income.

The organization of the rest of the paper is as follows. The second section discusses the officially nonexistent, albeit very easy to observe, racist attitudes that prevail among whites and white/Mestizos and the consequent overt preference for the European appearance across Mexican society. In the third section it is argued that the persistent high unemployment allows employers to be economically efficient when they consider their preference for the European appearance in their promotion and hiring decisions. The fourth section argues that free markets could help reduce the racial income inequality, but that the implementation of the required reforms faces stern opposition from the dark skinned and from the white oligarchy. In the fifth section a few key implications of the racial hierarchy for foreign executives working in Mexico are very briefly described. The sixth section contains conclusions. 


\section{RESILIENT RACIST ATTITUDES AND THE PREFERRED RACIAL APPEARANCE}

Virulent and hateful racial animosity is non-existent in Mexico. For this reason, most Mexicans are quite convinced that their society is free of any form of racial prejudices. Despite this widespread belief, racist attitudes have been firmly held by many whites and white/Mestizos for as long as the country has existed.

From the time of the Independence (1821) to the beginning of the Diaz regime (1876), whites openly expressed their conviction that they were racially superior to the Indian and the Mestizo. The ascendancy of Benito Juarez to the presidency, Mexico's only Indian president, during the $1860 \mathrm{~s}$ did not create social or economic conditions that would have induced the white minority to abandon their feelings of racial superiority (Stavenhagen, 1994, pp. 332-335). During the Diaz regime (1876-1910), the government and the oligarchy, which was entirely white, openly accepted the ideology postulating that dark-skinned people were naturally inferior and that only the white man was capable of developing a nation (Herring, 1968, p.328; Knight, 1990, p. 78).

During the 71 years (1929-2000) that the Partido Revolucionario Institucional, the PRI, controlled Mexican politics, government officials never made public statements about the racial issues that Mexican society faced. The PRI governments, however, glorified the Indian past in the country's official history and enthusiastically embraced the ideology of the Cosmic Race developed by Jose Vasconcelos, Mexico's leading intellectual of the 1930s. The Cosmic Race, as Vasconcelos called the Mestizo race, was inherently superior due to its mixed cultural and racial heritage (Knight, 1990, pp. 85-100; Stavenhagen, 1994, pp.335-336).

The glorification of the Indian past, the adoption of the Cosmic Race ideology and the economic progress that has been achieved since 1929, have not eliminated the racist attitudes of whites and white/Mestizos. In a study done by the OECD at the end of the 1960s, Mexico's leading entrepreneurs, all of whom were of exclusive European ancestry, very openly expressed their firm conviction that Indians and Mestizos were racially inferior (Derossi, 1971, pp.136-149). Twenty five years later, in the early and mid 1990s, the pervasive presence of racist attitudes among whites and white/Mestizos was reported again in books and articles published as a result of the implementation of the North American Free Trade Agreement, the NAFTA (Nevaer, 1995, pp. 101-103). More recently, in 2005, Carlos Monsivais, one of Mexico's most respected intellectuals, published an essay dealing with the issue of race in Mexico. Monsivais' arguments indicate that, although adamantly denied by Mexican society, the conviction that Indians and Mestizos are racially inferior continues to be firmly held by the vast majority of whites and white/Mestizos (Monsivais, 2005).

Most Mexicans also adamantly deny that there is a preferred racial appearance in their society. This denial, however, does not agree with what can clearly be seen in printed ads, T.V. commercials and ads in the internet. In these publicity channels, the great majority of the models have European appearance, very few have Mestizo appearance and none have Indian appearance ${ }^{2}$. Given the current and historical income distribution, the use of models of European appearance would be expected in the publicity of luxurious, sophisticated and very expensive goods and services. However, the products and services advertised through these publicity channels include basic processed foods, cigarettes, beer, diapers, soft drinks, working class hotels in Mexican resorts and many other products and services whose main buyers are dark skinned consumers. Even in the publicity CDs of exclusive residential developments, like one called Lagos del Sol in the Riviera Maya, the models hired to represent the brick layers building the houses are of European appearance, despite the fact that brick layers in Mexico are Indians and Mestizos of dominant Indian appearance.

According to marketers, the use of models of European appearance to advertise the vast majority of products and services is done because Indians and Mestizos prefer the European appearance over their own, not because they consider themselves racially inferior ${ }^{3}$. So, across Mexican society, either as a result of racist attitudes and/or as a result of considering the European appearance to be more attractive than other racial appearances, there is an overt preference for the European appearance, notwithstanding that this is not the appearance of the majority of the population. 


\section{THE EMPLOYERS' PREFERRED RACIAL APPEARANCE}

The mere existence of this preference is not, however, sufficient to link it to the observed racial economic hierarchy. For this link to exist, the preference for the European appearance must play a systematic role in decisions that affect individual incomes. Among the most important decisions of this type, if not the most important, are those regarding the hiring and promotion of personnel.

Basic microeconomic theory shows, however, that these decisions should not be influenced by racial appearances or by any other non-job related characteristics of the employees; for hires and promotions should be based solely upon the skills of the applicants and the requirements of the job (Landsburg, 2002, pp. 556-557). This reasoning, although theoretically valid, ignores three important features of the Mexican economy, namely: limited to non-existent competition in many consumer markets; persistent double digit rates of unemployment in blue collar and white collar labor markets; and practical absence of highly sophisticated jobs that require $\mathrm{Ph}$.Ds in science and engineering (Teichman, 2004, pp. 212-213 ; UNAM, 2007; INEGI, 2007).

The limited to non-existent competition in consumer markets allows producers to obtain profits even if they are economically inefficient; whereas the other two features assure employers of consistently having more than enough qualified applicants for the vast majority of job openings. Hence, when deciding whom to promote or whom to hire, employers have been in the position of considering, if they wished, non-job related attributes of the candidates, like racial appearance. Employers who consider the racial appearance of applicants in the selection and promotion of personnel are just introducing their personal preferences in this kind of decisions. This is, as argued below, a utility maximizing behavior.

Employers, it can be realistically assumed, derive utility from the daily interaction with their personnel. Among the factors that contribute to this interaction are the skills, personality, temperament, age, experience and racial appearance of the employees. Therefore, employers trying to maximize the utility that they derive from this interaction, must consider these and other factors in their promotion and hiring decisions. To determine if this maximization affects the selection of candidates of different racial appearances, a typical utility function will be borrowed from consumer theory. To keep, however, the analysis as simple as possible, the only factors that will be considered in this utility function are skills, racial appearance and wage. So, the proposed utility function is:

$\mathrm{U}=\mathrm{S}^{\alpha} \mathrm{R}^{\beta} \mathrm{W}^{-1}$

where $\mathrm{U}$ is the utility the employer derives from the interaction with a given employee, $\mathrm{S}$ and $\mathrm{R}$ are respectively, units of skills and European racial appearance, and $\mathrm{W}$ is the wage for the job.

The minimum value of $\mathrm{S}$ and $\mathrm{R}$ is assumed to be one. This happens when the employee has the basic skills needed for the job and has no European features at all, i.e., when the employee is an Indian who has the skills that meet the job requirements. W's exponent is minus one because the lower the salary or wage to pay, the more utility the employer obtains; whereas the values of $\alpha$ and $\beta$ are determined by the importance that skills and racial appearance have for each employer. These values, however, are assumed to be limited by the condition that $\alpha+\beta=1$, so the utility the employer derives, separately, from skills and European appearance increases at a decreasing rate.

Four hypothetical scenarios will be discussed next. In all of them it will be assumed that an employer with preferences represented by (1) and with a job to fill, has a pool of applicants whose racial appearances go from Indian and Indian/Mestizo, to individuals of complete European appearance. This assumption limits the applicability of the scenarios to discuss to white collar jobs, which include jobs for university graduates, and to the most qualified blue collar jobs. This limitation does not invalidate the analysis, since it is precisely in the socioeconomic classes formed by the occupants of these types of jobs that the racial economic hierarchy is easily observable. A second assumption for the four scenarios to discuss is that for all job openings there is an excessive supply of qualified applicants; that is, for all job openings there are many candidates whose $\mathrm{S}$ is equal to or greater than one. This assumption is based upon the above mentioned combination of chronically large unemployment and very limited number of job openings requiring advanced degrees in science and engineering. 
In the four scenarios to discuss the objective is to deduce the hypothetical circumstances regarding wage, racial appearance and skills that would induce an employer to select a dark skinned applicant over a white applicant. In the four scenarios, $\mathrm{W}^{*}$ will denote the salary for the job to fill that would be paid in labor markets where unemployment is minimal, i.e., the maximum salary that employers would be willing to pay when labor surpluses are minimal. In the four scenarios $\mathrm{U}_{\mathrm{E}}$ and $\mathrm{U}_{\mathrm{D}}$ will denote the utility the employer would derive from interacting, respectively, with the top white applicant and the top dark-skinned applicant. Thus, $S_{E}$ and $R_{E}$ are the units of skills and European racial appearance that form $\mathrm{U}_{\mathrm{E}}$; while $\mathrm{S}_{\mathrm{D}}$ and $\mathrm{R}_{\mathrm{D}}$ are the units of skills and European racial appearance that generate $U_{D}$. In the four scenarios it is consider that $R_{E}>R_{D}$.

The employer, in the first scenario, faces the following conditions: all applicants have the same level of skills, so $\mathrm{S}_{\mathrm{E}}=\mathrm{S}_{\mathrm{D}}$ and the wage is fixed at $\mathrm{W}^{*}$, thus economic efficiency regarding the wage to pay to the selected candidate is assured. In this scenario, selecting the applicant who has the higher R, the most European looking applicant, is the option that maximizes the employer's utility.

This scenario is a simplification of the very rare situations when the applicants are homogeneous in terms of their skills and the salary, despite the excessive number of applicants, is downwardly inflexible. Nonetheless, it shows that under these conditions, Indian and Indian/Mestizo applicants are not going to be hired or promoted as long as there are applicants whose appearance is fully or partially European because the fact that $R_{E}>R_{D}$ causes $\mathrm{U}_{\mathrm{E}}>\mathrm{U}_{\mathrm{D}}$.

In a second scenario the wage is also set equal to $\mathrm{W}^{*}$, while $\mathrm{S}$ varies among the candidates. Under these conditions selecting a dark skinned applicant happens if $\mathrm{U}_{\mathrm{E}}<\mathrm{U}_{\mathrm{D}}$. For this to happen, however, it is necessary that $\mathrm{S}_{\mathrm{E}}$ $<S_{D}$, given that $R_{E}>R_{D}$ and that the salary is the same for all candidates. Hence, for a dark skinned individual to be selected, she/he has to be more skilled than the most qualified white applicant.

In a third scenario $S_{E}=S_{D}$, and as before, $R_{E}>R_{D}$. However, due to the excessive number of applicants, it is assumed that the employer has the power to set the wage for the job, $\mathrm{W}$, below the $\mathrm{W}^{*}$, defined above as the salary for the job to fill that would be paid in labor markets where unemployment is minimal. Under these circumstances, the selection of a dark skinned applicant happens if the dark skinned applicant accepts a lower salary than the salary accepted by the most qualified white applicant. That is, under the circumstances assumed in this scenario, and defining $\mathrm{W}_{\mathrm{D}}$ ad $\mathrm{W}_{\mathrm{E}}$ as the wages for the most qualified dark skinned and white applicants, the employer the dark-skinned applicant would be selected if the condition $\mathrm{W}_{\mathrm{D}}<\mathrm{W}_{\mathrm{E}} \leq \mathrm{W}^{*}$ prevails.

What these arguments indicate is that when the most qualified white and dark skinned candidates have the same skills and the wage is downwardly flexible, the dark skinned candidate can be given the job if she/he agrees to work for less than the white candidate. By doing this the dark skinned candidate gives a financial reward to the employer and undervalues her/his skills.

The fourth, and last, scenario assumes: $R_{E}>R_{D}$ as in previous scenarios, $S_{E}<S_{D}$ and a downwardly flexible salary, that is, a salary that may be less than $\mathrm{W}^{*}$. Under these conditions the dark skinned candidate could be selected without having to accept a lower salary than the most qualified white candidate, if the superiority of her/his skills are enough to generate the result $\mathrm{U}_{\mathrm{E}}<\mathrm{U}_{\mathrm{D}}$. This outcome, although possible, is very unlikely in labor markets where jobs requiring very high skill levels, like Ph.Ds in engineering and the sciences, are very few. So for the great majority of jobs the fact that $S_{E}<S_{D}$ would not be enough to cause $U_{E}<U_{D}$. Hence, like in scenario three, in scenario four the dark skinned candidate can be given the job if the condition $\mathrm{W}_{\mathrm{D}}<\mathrm{W}_{\mathrm{E}} \leq \mathrm{W}^{*}$ prevails.

These scenarios are, of course, theoretical. However, they show the outcomes that dark skinned job seekers face when they compete with applicants who are white or white/Mestizos in labor markets where large labor surpluses are permanent and where employers have an overt preference for the European appearance. These outcomes go from staying unemployed, which is what the first scenario describes, to accepting jobs for which they are overqualified and/or underpaid. In all of these scenarios employers are economically efficient, since in all of these employers maximize the utility that they derive from the interaction with their employees without having to 
employ under qualified personnel. This, however, does not mean that allowing the overt preference for European appearance to influence hires and promotions is, from an economic development perspective, harmless.

\section{HAMPERING ECONOMIC DEVELOPMENT}

The economic inefficiencies generated by allowing racial appearance to influence hires and promotions are the result of the wage differentials explained in scenarios three and four discussed above. As can be recalled, in these scenarios $\mathrm{W}^{*}$ represents the salary for the job to fill that would be paid in labor markets where unemployment is minimal, while $\mathrm{W}_{\mathrm{D}}$ and $\mathrm{W}_{\mathrm{E}}$ represent the wage for the most qualified dark-skinned and white applicants. In both scenarios a dark-skinned candidate who is at least as qualified as the most qualified white candidate, could be selected if the inequality $\mathrm{W}_{\mathrm{D}}<\mathrm{W}_{\mathrm{E}} \leq \mathrm{W}^{*}$ prevailed. The first part of this inequality: $\mathrm{W}_{\mathrm{E}} \leq \mathrm{W}^{*}$, is attributable to persistent large unemployment; whereas the second part: $\mathrm{W}_{\mathrm{D}}<\mathrm{W}_{\mathrm{E}}$, is attributable to the overt preference for the European appearance. This part of the wage differential, entirely caused by racial appearance, aggravates Mexico's notoriously biased income distribution in favor of employers and, as argued next, hinders the progress of higher education.

Currently in Mexico, the progress of higher education is the responsibility, to a large extent, of the expensive private universities. These are the universities where tuition is no less than $\$ 3,000$ per semester ${ }^{4}$. From the perspective of economic development, these private universities have this responsibility because they are educating the future professionals of the upper classes, and because state universities are under severe political pressure to increase enrollment thereby lowering academic standards (Lopez Obrador 2006). Mexico's expensive private universities have, however, no incentive to fulfill this responsibility.

The absence of this incentive is the result of the fact that graduates of private expensive universities earn more than graduates of state or pubic universities. This wage differential tells expensive private universities that, according to the labor markets, they are doing a better job than the state universities; and therefore, that there is no reason to improve the quality of the education that they deliver. This reasoning is, however, incongruent with two well known characteristics of these universities: the total neglect of research and the formation of teaching staffs with adjunct professors who normally lack advanced degrees and have full time employment outside of academia. Hence, the assumed academic superiority of the private universities cannot be the reason why graduates of private universities earn more than their counterparts from state universities.

To find this explanation is enough to look at the racial composition of the student populations. In expensive private universities whites, white/Mestizos and Mestizos who strongly identify with the white segment of society form the majority of the student population; while in state universities, the great majority of the student population is dark-skinned. Given this racial composition and the overt preference for the European appearance in labor markets, it follows that the graduates of expensive private universities will earn more than the graduates of state universities. Thus as long as this combination is allowed to create a wage differential in favor of the graduates of expensive private universities, the expensive private universities will keep doing what are they are doing, i.e., delivering an education of mediocre quality ${ }^{5}$.

\section{TRUE FREE MARKETS: A POSSIBLE SOLUTION OPPOSED BY THE DARK-SKINNED AND THE WEALTHY WHITE.}

For the deeply entrenched preference for the European appearance among employers to disappear, employers need a very strong motivation to exclusively consider, albeit reluctantly, the skills of the applicants in hiring and promotion decisions. This need can only materialize in markets where competition is intense. According to the OECD, this could happen by implementing legal reforms that actually promote free markets in all sectors of the economy. These reforms, also according to the OECD, have the potential of attracting foreign investment and generating sustained rates of growth of $4 \%$ or more per year, which is what Mexico needs to markedly ameliorate its unemployment problem (OECD, 2005, p. 9). 
Regarding labor, these reforms consist in reducing the excessive protection that current labor laws give to workers and employees. These laws make it very expensive to hire and fire labor, thereby restricting the growth of the demand for labor. Regarding business, the reforms recommended by the OECD would reduce the current excessive level of regulations of consumer markets, simplify the cumbersome and expensive bureaucratic procedures for opening new businesses, and remove the concessions that, de facto, have created monopolies and oligopolies in the following sectors: banking, cement, energy, retail, steel, telecommunications, television, tortilla and transportation (OECD, 2005, pp.9-12). These reforms, regardless of the economic benefits that they may generate for the entire society, are not likely to be implemented in the near future.

For the dark-skinned majorities the free market policies and reforms implemented in the last eighteen years have brought some benefits to the consumer. But, from their perspective, these policies and reforms have also had the following costs: lower salaries, reduced access to higher education, more expensive housing and transportation, and an increased dependency on foreign capital. For the dark-skinned majorities there is no doubt that the costs of these policies have been larger than the benefits (Lopez Obrador, 2006). Additionally, for the political leaders of the dark skinned majorities accepting the implementation of more free market policies would be an ideological defeat. Hence, regardless of what actual economic benefits the adoption of free market policies have generated, and could generate, for the poor and working classes, the dark skinned majorities oppose and will continue to oppose the implementation of most legal reforms aimed at promoting free markets.

The wealthy white oligarchy has benefited greatly from the free market policies that have been implemented in the last fifteen years (Chong and Lopez-de- Silanes, 2003, pp.22-27). The wealthy white oligarchy, furthermore, has no ideological quarrel with these policies and is fully convinced that true free market policies and reforms will generate faster economic growth, larger markets, and economic efficiency. This favorable view of free markets is, however, quite incongruent with the fact that after eighteen or more years of free market policies and four pro business administrations, consumer and resource markets continue to be dominated by oligopolies and monopolies (The Economist Intelligence Unit, 2005, p.1). This incongruence finds explanations in the behavior of the leadership of Mexico's private sector when important free market reforms or policies were going to be implemented. In 1980 when the government proposed joining the GATT, the private sector defeated this proposition. In the early nineties, the private sector accepted the NAFTA after making sure that many of its privileges were kept and after coming to the conclusion that this treaty was the best option for avoiding an economic collapse like the one experienced in 1982-1983 (Tornell, 1995, pp.53-54). Later during the Fox administration (2000-2006), the leadership of the private sector defeated initiatives to put some transparency in the stock market and to open the television and telephone sectors (O'Grady, 2006; Heritage Foundation, 2006, p.1). This behavior indicates that the private sector only supports those free markets reforms and policies that do not diminish their monopolistic or oligopolistic privileges. So, the private sector may support the OECD's recommendations regarding labor; but there is no reason to expect that the private sector will support the OECD's recommendations dealing with the reforms needed to promote competition in resource and consumer markets.

It is, therefore, up to the economic authorities of the federal government to convince Mexico's Congress to adopt the reforms recommended by the OECD. These authorities began to lobby Mexico's Congress to adopt free markets policies and reforms in the early nineties. But as mentioned above, eighteen years and four pro-business administrations later, consumer and resource markets continue to be dominated by monopolies and oligopolies. Given this record, it is unrealistic to expect that the economic authorities will be able to convince Mexico's Congress, in the near future, of the need to adopt reforms and policies that truly promote free markets. Hence, it is also unrealistic to expect that, in the near future, the overt preference for the European appearance will stop influencing hiring and promotion decisions.

\section{A FEW IMPORTANT IMPLICATIONS FOR FOREIGN EXECUTIVES.}

A detailed discussion of the business implications that the overt preference for the European appearance has for foreign executives working in Mexico is beyond the scope of this paper. However, three of these implications will be briefly described. 
Foreign executives transferred to Mexico, but who have little or no experience in Mexico, may assume that in the formation of their staffs all that should matter are the professional skills of the members of this staff. Nonetheless, if this staff deals with representatives of Mexico's oligarchy, then this staff must include, in the most visible positions, individuals who are white or white/Mestizos. Otherwise, the social prestige of this executive will suffer.

The second implication has to do with the academic quality of universities and the hiring of engineers and other professionals. Foreign executives will hear from members of Mexico's upper classes that the expensive private universities are quite superior to the state universities. Foreign executives will also notice that the graduates of expensive private universities tend to ask for higher salaries than the graduates of state universities. Yet, as mentioned above, the education delivered by the expensive universities tends to be of mediocre quality. Thus, when hiring engineers and other professionals, foreign executives would make a mistake if they equate the quality of the academic background of the candidates with the salaries that they are asking.

Finally, the third implication deals with the treatment of the labor force, especially blue collar workers. Foreign executives will run across examples of Mexican employers who badly mistreat their labor forces. In those occasions when the Mexican employer is of exclusive European origin, the mistreatment may have racial overtones. Mexican employers who do this have the government connections that allow them to get away with this offense and, of much importance, neither government officials nor the unions would see racial reasons behind any mistreatment of the labor force. But if a foreign employer does it, the racial issue is likely to appear. This will increase the cost and the complexity of any labor dispute. So, foreign executives should not follow the examples of mistreatment of the labor force that they will certainly observe in some Mexican employers.

\section{CONCLUSIONS}

A common explanation for the existence of the racial economic hierarchy, among Mexicans who recognize its existence, is that such a hierarchy is a simple remnant of pre-revolutionary Mexican society. This explanation is invalidated by two easily observable facts: the existence of firm racist attitudes among whites and white/Mestizos, and the overt preference for the European appearance across society.

This overt preference influences income distribution because employers derive utility from the interaction with their employees, and racial appearance is one of the factors that are part of this interaction. Employers can consider this, non-job related factor in their personnel decisions, because the persistent large labor surpluses assure them of an excessive supply of qualified candidates for most positions.

Despite contribution to the utility that employers derive from the interaction with their personnel, the overt preference for the European appearance is detrimental to the process of economic development for at least two reasons. First, this preference aggravates Mexico's notoriously biased income distribution; and second, it gives expensive private universities an incentive to maintain their current low academic standards.

To be able to implement the reforms needed to eliminate, or at least to diminish, the influence of the preference for the European appearance in hiring and promotion decisions, Mexico's government has to accomplish two very difficult tasks. It has to convince the dark-skinned that free markets will improve their economic lot; and it has to defeat the lobbying of the white oligarchy against the adoption of reforms that remove their economic privileges. Given the poor record that the government has had in both tasks, there is no reason to expect that the needed reforms will be adopted any time soon.

\section{END NOTES}

${ }^{1}$ Many Mexicans would not agree with this racial classification. However, the CIA's classification is consistent with the racial classification reported in the 1930 Census, which was the last census when the authorities made an effort to determine the racial composition of Mexican society.

${ }^{2}$ The only T.V. adds where Indians and dark-skinned Mestizos appear are those of political nature and those that promote hygiene or civil behavior in public places. 
${ }^{3}$ This is the opinion of two professors of marketing of the Universidad de las Americas-Puebla interviewed in 2003. One of these professors has a Ph. D. in marketing from Texas A\&M University and was, until 2005, dean of the Business School of this university.

${ }^{4}$ There are more than 200 private universities in Mexico, but only about 20 of them charge a tuition of $\$ 3,000$ or more per semester. The largest of these expensive universities is the Instituto Tecnológico y de Estudios Superiores de Monterrey, which has an enrollment of close to 90,000 students in its 35 campuses. The most elitist is, perhaps, the Universidad Anáhuac and the most expensive is the Universidad de las Americas-Puebla where the tuition approaches $\$ 4,000$ per semester.

${ }^{5}$ A notable exception is the Instituto Tecnológico Autónomo de Mexico, the ITAM. This institution delivers an excellent education in the area of economics and in other areas related to business. In this institution a good number of the professors are full time and many of them have advanced degrees from very prestigious American and European universities

Rutilio Martinez is an associate professor of statistics at the Monfort College of Business of the University of Northern Colorado. He has taught at this school for 14 years. From 2000 to 2005 he was a partner of CG Americas, a Denver firm that promoted businesses between the USA and Mexico. He teaches a lass about Latin American business culture and economics in Furtwagen University in Germany. He has a Ph. D. in economics from Vanderbilt University.

Cris de la Torre is an associate professor of finance at the Monfort College of Business of the University of Northern Colorad. He has taught at this school for ten years. He has more than 15 publications in peer reviewed journals in the areas of finance and law. His Ph. D. in finance is from the University of Texas at Austin and his JD is from the University of Colorado.

\section{REFERENCES}

1. Central Intelligence Agency. (2006). World Factbook. Retrived August 28, 2006, from http://www.cia.gov/cia/publicationsfactbook/index.html

2. Derossi, F. (1971). The Mexican Entrepreneur. Paris, France: Development Centre of the Organisation for Economic Co-opertaion and Development.

3. Chong, A., \& Lopez-de-Silanes, F. (2003). The Truth about Privatization in Latin America. Washington, D.C.: Inter-American Development Bank.

4. Hall, G., \& Patrinos, H.L.(2004). Indigenous Peoples, Poverty and Human Development in Latin America:1994-2004. Retrieved June 23, 2005, from www.worldbank.org/lacindigenous

5. Heritage Foundation (2006). 2006 Index of Economic Freedom. MEXICO. Retrieved July 25, 2006, from http://www.heritge.org/research/features/index.

6. Herring, H. (1968). A History of Latin America from the Beginnings to the Present. New York, NY: Alfred Knopf.

7. INEGI. (2007). Banco de Información Económica. Empleo y Desempleo. Retrieved November 18, 2007, from http://dgcnesyp.inegi.gob.mx

8. Knight, (1990). Racism, Revolution and Indigenismo: Mexico, 1910-1940. In R. Graham (Ed.), The Idea of Race in Latin America, 1870-1940. Austin, TX: University of Texas.

9. Landsburg, S. (2002). Price Theory and Applications. Fifth Ed. Mason, OH: South-Western

10. Lopez Obrador, A. (2006).20 Compromisos Básicos de Gobierno Legítimo de México. Retrieved December 31, 2006, from http://www.gobiernolegitom.org.mx

11. Monsivais, C. (2005, May 22). Racismo alrevés es Nunca lo dije. Proceso, 1490,. 32-34

12. Nevaer, L. (1995). Strategies for Business in Mexico. Free Trade and the Emergence of North America, Inc. Westport, CT: Quorum Books.

13. OECD. (2005, September). Economic Surveys: Mexico. Paris, France: OECD

14. O'Grady, A. (2006, February 10). A Telecom Monopoly Cripples Mexico. The Wall Street Journal. p.A19

15. Stavenhagem, R. (1994). Challenging the Nation-State in Latin America. In J.I. Dominguez (Ed.), Essays on Mexico, Central and South America. New Yorl, NY.: Garland Publishing.

16. Teichman, J. (2004). Political Challenges to Equitable Development in Latin America. In G. Indrat. (Ed.), Economic Reforms, Growth and Inequality in Latin America. Aldershot, England: Ashgate Publishing Limited. 
17. The Economist Intelligence Unit. (2005, September). Country Commerce: Mexico. New York, NY: The Economist Intelligence Unit.

18. Tornell, A. (1995). Are Economic Crises Necessary for Trade Liberalization and Fiscal Reform? The Mexican Experience. In R. Dornbusch \& S. Edwards (Eds.), Reform, Recovery and Growth: Latin America and the Middle East. Chicago, Ill.: The University of Chicago Press.

19. UNAM (2007). Carreras cuyos empleados recibieron el mayor ingreso promedio durante el último año. Cilas.IIEc-UNAM. Facultad de Economía, UNAM. Retrieved August 17, 2007, from http://www.misalrio.org/main/Salarios

20. Wagley (1994). On the Concept of Social Race in the Americas. In J.I. Dominguez (Ed.), Essays on Mexico, Central and South America. New Yorl, NY.: Garland Publishing

\section{NOTES}


NOTES 